\title{
Transvestite Motivation In Preventive Transmissin Of Hiv Aids At The Sememi Puskesmas In Benowo Sub- Direct Of Surabaya
}

\author{
Nur Hidaayah ${ }^{1}$, Cholik Anwar ${ }^{2}$ \\ \{Nahdlatul Ulama nurhid@unusa.ac.id, Nahdlatul Ulama1130116021@student.unusa.ac.id\} \\ Departement of Nursing Faculty of Nursing and Midwifery University of
}

\begin{abstract}
Sexually transmitted infections and HIV AIDS are increasing year by year, especially in key transgender populations and male sex partners in Indonesia, transsexuals from $5.8 \%$ to $8.2 \%$ of male sex partners of $2.5 \%$ to $7.4 \%$. The purpose of this study was to determine the motivation of waria in preventing HIV AIDS transmission at Sememi Public Health Center, Benowo Sub-district, Surabaya City. The design of this research is descriptive with cross sectional approach. The population was 40 transvestites taken using Non Probability Sampling technique of total sampling type. The variable is motivation. Data collection using questionnaires. Data analysis in the form of identification and interpreted in scale. The results of this study showed that most transvestites $(67.5 \%)$ had a strong motivation in preventing HIV AIDS transmission at Sememi Public Health Center, Benowo Sub-district, Surabaya City. Strong motivation in preventing HIV transmission of AIDS belongs to transvestites. is expected to be reflected in attitudes and behaviors to prevent transmission, so the spread of transmission of sexually transmitted infections and HIV AIDS can be controlled.
\end{abstract}

Keywords: Motivation, Transgender, HIV AIDS Prevention

\section{Introduction}

Sexually transmitted infections (STIs) are a public health problem and pose a burden of morbidity and even mortality in developing countries. Preventive and treating IMS can reduce the risk of HIV transmission through sexual contact. The presence of IMS in the form of inflammation or ulceration will increase the risk of HIV infection during unprotectedsexual intercourcse between someone who has been infected with an IMS and his healty partner (Indonesian Ministry of Health in 2015).

Until 2013, cases of HIV and AIDS in indonesia have spread in 368 out of 497 distric/cities (72\%) in all Provinces. The number of new HIV cases each year reaches around 20.000 cases. In 2013 there were 29.037 new cases, with 26.527 (90,9\%) of reproductive age (15-49 years) and 12.279 of whom were women. New HIV cases in the group of housewives at $428(15 \%)$ which if transmit HIV infection to their babies. 
The spread of sexually transmitted infections and HIV AIDS in the last 10 years began the movement that originally started from the use of unsterile needles in injecting drug users turned into transmission through sexual contact. Based on estimates made by the Ministry of Health in 2012, there are around 9 million people in Indonesia who are at high risk of contracting or transmitting HIV. Of the total 75,000 injecting drug users, 250,000 women are sex workers directly and indirectly, 1.15 million men who have sex with men and transgenders, and 7 million male sex buyers. In addition, 5 million high-risk couples, including housewives who are very vulnerable to contracting HIV (Indonesian Ministry of Health Data, 2015).

In 2007, 2009, 2011 and 2013, the Ministry of Health conducted an Integrated Biology and Behavior Survey (STBP) and it was concluded that HIV prevalence decreased or was stable in IDUs and FSWs but increased in waria and MSM. With an increase in HIV prevalence in key population groups and a large number of high-risk men, it is projected that there will be an increase in new HIV infections in low-risk women and MSM, as shown in the following table:

Table 1.Trends in HIV Prevalence

\begin{tabular}{|c|c|c|c|c|c|c|}
\hline POPCLATION & BBS $200^{\circ}$ & BBSS2011 & TREND & BBSSOOOY & BBSSOO1I & TREND \\
\hline 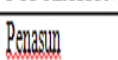 & 29,8 & 19.5 & Decteasel & 8.8 & 14.4 & Incerased \\
\hline WPSInderect & 5.3 & 3.1 & Decreasel & 3.5 & 1.5 & Dectesiel \\
\hline WPS direct & 8.4 & 90 & Inceased & 5.7 & 6.1 & Stable \\
\hline Waria & 9.8 & 11.9 & Inceased & 58 & 8.2 & Incesse \\
\hline LSL & 1.9 & 6.5 & Incerased & 2.5 & 7.4 & incerse \\
\hline
\end{tabular}

Sources: STBP 2007, 2009, 2011 and 2013, Ministry of Health Republic of Indonesia in 2015

\section{Research Methods}

Types and Design Research in this study is descriptive with cross sectional approach. This study aims to make a picture or description of the motivation of transvestites in preventing the transmission of HIV AIDS in Sememi Health Center, Benowo District, Surabaya City.

The research population of all transvestites in the western area of the city of Surabaya who were fostered by the Sememi Community Health Center were 40 transvestites.

The sample in this study was transvestites in the western area of the city of Surabaya who were assisted by Sememi Community Health Center.

Transvestites in this study were drawn from populations that met the inclusion criteria in the study:

a. Transvestites are willing to be respondents.

b. Located in the western region of the city of Surabaya

c. Transvestite is more than 17 years old

d. It is built by Sememi Community Health Center

Transvestites in this study were not drawn from populations that met the exclusion criteria in the study:

a. Transvestites who have received Health Education about HIV AIDS

b. Transvestites who are currently ill (MRS)

c. Transvestites who have never come to the Sememi Community Health Center 
The sample size in this study was 40 transvestites.

How to Take Samples

Sampling in this study using non-probability sampling techniques. The technique used is total sampling, that is, all transvestites who were sampled were given a research questionnaire.

In the Sememi Puskesmas hall building during the "Friends of the Peer Group" KDS (Peer Support Group) activities as well as during the "Blok M" CBO (Community Base Organization) activity using a questionnaire created by the researchers.

Time of Study in May 2018.

Data Processing and Analysis Techniques

1. Editing (data selection)

Re-examine the notes (data) to find out whether the data is good enough and can be prepared immediately for the purposes of the next process. In this study the data obtained will be examined again with a view to knowing the completeness of the answers given.

2. Scoring

Includes giving a score on the answers that have been given by respondents

3. Coding

Stages of researchers provide code in each category that is in the variable.

a. Strong Motivation: $67 \%-100 \%$

b. Moderate motivation: $34 \%-66 \%$

c. Weak Motivation: $0 \%-33 \%$

4. Tabulating

Grouping data into certain models according to the properties they have. The process of compiling data in tabular form. The results of data analysis in the form of a percentage, interpreted using a scale:

$100 \%$ : All of it

$76 \%-90 \%$ : Almost all

$51 \%-75 \%$ : Most

$50 \%$ : Half

$26 \%-49 \%$ : Nearly half

$1 \%-25 \%$ : A small portion

$0 \%$ : None

Research Ethics

1. Informed Consent (Approval Sheet)

The research consent sheet was given to respondents, namely transvestites in the western part of the city of Surabaya, the aim being that the subjects knew the intentions and objectives of the researcher and the impact of the study. If they are willing to be investigated, they must sign the consent form that has been provided by the researcher, if the subject refuses to do the research, the researcher does not force.

2. Anominity (No Name)

To maintain the confidentiality of the respondent's identity, the researcher will not put the respondent's name on the data collection sheet (questionnaire). Sheets are only given a certain code number.

3. Confidentiality

Confidentiality of information that has been collected from subjects is guaranteed confidentiality by researchers, only certain data groups will be presented or reported as research results. 


\section{Result and Discussion}

Sememi Community Health Center was established in 1986 and has continued to grow until now, Sememi Community Health Center with the usual type, with maternity hospitalization. The vision of the Sememi puskesmas is that community partners realize the healthy, independent and globally competitive Benowo District in 2025. The mission of the Sememi puskesmas is to provide whole-hearted and quality services with available resources, making the Sememi Puskesmas a health information center for the community, forging partnerships with various communities, improve the health of individuals, families and the environment by working values with the principles of $5 \mathrm{~S}$ (smile, greetings, greetings, courtesy), discipline at work, professionalism at work, serving patients wholeheartedly, service in accordance with working hours, responsible for working.

The Sememi Community Health Center is located in two ex-localization areas, Kandangan and Sememi, with a total of 90 homesteads, 90 pimps and around 400 CSWs and 60 transgender people (data as of February 2013). At the end of 2013 to be exact in September, the Surabaya City Government had officially closed the Klakahrejo localization and in December 2013 a Sememi localization closure was also carried out. The commitment of the Surabaya City Government to realize "Surabaya Free of Prostitution" was re-established by the closure of the largest localization complex in Southeast Asia

namely Dolly in September 2014. The boundaries of the Sememi Benowo District Health Center

North: Madura Strait

South: Sambi Kerep

West: Pakal District

East: Tandes District

The work area of the Sememi Community Health Center: Benowo District, covers 4 Kelurahan:

1. Kelurahan Kandangan

2. Sememi Village

3. Pond of Oso Wilangon Village

4. Father Kali Sari Village

In 2014 the Surabaya Mayor's statement conveyed his vision and mission of the development of the city of Surabaya including that in 2015 Surabaya must meet "3 zero" namely:

1. The absence of new HIV-AIDS infections

2. There is no discrimination against people with HIV-AIDS

3. There are no deaths related to HIV-AIDS

Improvement of health services provided by Sememi Public Health Centers in efforts to control sexually transmitted infections (STIs) and HIV AIDS, some of them by opening services related to STIs and HIV AIDS include: registration counters, general poly, dental poly, MCH poly, Batra poly, Sanitary poly, counseling nutrition, Reproductive clinic, laboratory, CST poly, TB poly, Psychology poly, pharmacy and other outdoor services. 
Table 2. Frequency Distribution of Respondents by Age of Transvestite at Sememi Surabaya Health Center, in 2018

\begin{tabular}{ccc}
\hline Age (Years) & Frekuency & Persentase (\%) \\
\hline $17-25$ & 1 & 2,5 \\
$26-35$ & 23 & 57,5 \\
$36-45$ & 12 & 30 \\
$46-55$ & 4 & 10 \\
\hline Total & 40 & 100 \\
\hline \multicolumn{2}{l}{ Source: Primary data for May 2018 }
\end{tabular}

Table 2 shows that of the 40 respondents, the majority (57.5\%) aged 26 years to 35 years.

Table 3 Distribution of Frequency of Respondents by Transvestite Education in Surabaya Sememi Health Center, in 2018

\begin{tabular}{lcc}
\hline Education & Frekuency $(\mathrm{N})$ & Persentase $(\%)$ \\
\hline Basic & 8 & 20 \\
Intermediate & 31 & 77,5 \\
High & 1 & 2,5 \\
\hline Total & 40 & 100 \\
\hline \multicolumn{2}{c}{ Source: Primary data for May 2018}
\end{tabular}

Source: Primary data for May 2018

Table 3 shows, of the 40 respondents, almost all respondents (77.5\%) had secondary education.

Table 4 Frequency Distribution of Transvestite Motivation in Preventing HIV AIDS Transmission in Sememi Health Center in Benowo Kota District, in 2018

\begin{tabular}{|c|c|c|}
\hline Variable & $\begin{array}{l}\text { Frekuensi } \\
(\mathrm{N})\end{array}$ & Presentase $(\%)$ \\
\hline Strong Motivation & 27 & $67,5 \%$ \\
\hline Medium Motivation & 12 & $30 \%$ \\
\hline Weak Motivation & 1 & $2,5 \%$ \\
\hline Total & 40 & $100 \%$ \\
\hline
\end{tabular}

Table 4 shows that of the 40 respondents, the majority of respondents $(67.5 \%)$ had a strong motivation of 27 respondents

Based on table 4, it shows that of the 40 respondents, most of them have strong motivation in preventing the transmission of HIV AIDS (67.5\%) as many as 27 respondents. high and is expected to help control the spread of HIV AIDS infection. The Ministry of Health conducted an Integrated Biology and Behavior Survey (STBP) and concluded that HIV prevalence decreased or was stable in IDUs and FSW (Female Sex Workers) but increased among waria and MSM. With an increase in HIV prevalence in key population groups and a large number of high-risk men, it is projected that there will be an increase in new HIV infections in lowrisk women and MSM.

The strong motivation possessed by key transgender populations in the Sememi Community Health Center in preventing transmission of HIV AIDS transmission in the city of Surabaya, especially in the work area of the Sememi Health Center is expected to have a large influence on the spread of HIV AIDS transmission in other key populations such as same sex 
male and male sex partners other high-risk men are female sex workers (FSW) and transsexual sex customers. Almost all transgender respondents (90\%) answered strongly agree on questionnaire question number 1 , this gives an indication that the intrinsic motivation of the waria individual is very strong so that the individual participates in trying to break the chain of HIV / AIDS transmission, especially to themselves.

Routine checks are carried out by transsexual key populations. This is illustrated in the answer to questionnaire number 9 , which is equal to $(88 \%)$, which is expected to be delivered to other key population communities so that they always carry out routine checks for early detection of HIV AIDS infection as well as for customers. Thus, the spread of HIV AIDS infection in the city of Surabaya, especially in Sememi Puskesmas will be easier to control.

General data including the characteristics of respondents by age according to table 3 shows that of the 40 respondents, most of the ages 26 years to 35 years $(57.5 \%)$ were 23 respondents, this illustrates the number of key transgender populations in the work area of the Sememi Puskesmas Benowo sub-district is spread from various types of age groups. Ministry of Health data shows that up to 2013, cases of HIV and AIDS in Indonesia have spread in 368 out of 497 districts / cities (72\%) in all provinces. The number of new HIV cases each year reaches around 20,000 cases. In 2013, 29,037 new cases were recorded, with 26,527 (90.9\%) of reproductive age (15-49 years). According to Notoatmodjo (2010) age affects the person's comprehension and mindset. As we get older the more we grasp the power of mind and mindset, so the knowledge he gets is getting better. Key transgender populations in the Sememi Community Health Center with different age characteristics, most of the ages 26 to 35 years $(57 \%)$ have sufficient maturity in determining their lives, especially related to the spread of HIV AIDS infection, with the mindset and knowledge possessed and strong motivation in preventing the transmission of HIV AIDS has made a major contribution in controlling the spread of HIV AIDS infection.

Table 4 shows that of the 40 respondents, showed that almost all respondents (77.5\%), as many as 31 respondents had secondary education. Education plays a role in the social aspects of society so that if a person's education is relatively low, his knowledge will be less while those whose education is higher will be better knowledge (Syamsianah, Mufnaetty.dkk 2010). A person with low education does not mean that he absolutely has low knowledge (Yuliana.dkk, 2014). Knowledge enhancement is not only obtained from formal education, but can also be obtained from non-formal education.

Education owned by transgender populations provides a great potential in transgender people, most of the education that is owned by non-formal education is possible because often these transgender communities participate in activities organized by non-governmental organizations (NGOs) related to prevention HIV AIDS transmission, with this capital motivation in individuals will increase in preventing transmission of HIV AIDS so that it is expected to reduce the prevalence of the spread of HIV AIDS transmission in the city of Surabaya, especially in the Benowo subdistrict.

Limitation

1. Researchers are beginners related to experience so there are many shortcomings in terms of preparation and adjustment.

2. Time limitations in terms of sample search for transgender community assisted by Puskesmas due to very high mobilization from transvestites.

3. The target area under study is formed by the Puskesmas and coordinated with the head of the Blok M Community Base Organization (CBO), so that if the chairman has other activities, the research activities will be difficult to carry out. 


\section{Conclusions}

The results of research conducted by researchers, the researchers concluded that the majority of transgender populations have a strong motivation in preventing the transmission of HIV AIDS in the western area of the city of Surabaya which is under the auspices of Sememi Puskesmas, Benowo District, Surabaya.

\section{Suggestion}

1. For Research Land

This research can provide an overview of information related to health problems in the work area of the health center and can be made policies, which are used effectively in efforts to prevent and control HIV AIDS infection.

2. For Educational Institutions

The educational institution can provide additional competence to students related to the prevention of HIV AIDS transmission.

3. For further researchers

The next researcher who is interested in this research can be used as a guide to develop this research by expanding other variables to make it better and more useful.

4. For Respondents

Key populations, especially transsexuals, should always play an active role in activities aimed at preventing the transmission of HIV AIDS, both socialization, health promotion and direct activities to the community.

\section{References}

[1] Penelitian Suatu Pendekatan Praktik. Jakarta: Rineka Cipta.

[2] Centers for Disease Control and Prevention. Basic information about HIV and AIDS. Available from: http://www.cdc.gov/hiv/topics/basic/

[3] Direktorat Jendral PP dan PL Kementrian Kesehatan RI. 2015. Laporan Situasi Perkembangan HIV/AIDS Di Indonesia 2015. Jakarta (Indonesia)

[4] Diyan Ratna Wahyuningtyas. 2013. Gambaran Motivasi Ibu Bekerja Dalam Pemberian ASI Eksklusif Di RW 01 Desa Ketajen Kecamatan Gedangan Kabupaten Sidoarjo. Tugas Akhir : Fakultas Keperawatan dan Kebidanan, Universitas Nahdlatul Ulama Surabaya.

[5] Friedman, Howard. S. 2008. Kepribadian: Teori Klasik Dan Riset Modern. Jakarta: Erlangga

[6] Hamzah B. Uno. 2008. Teori Motivasi Dan Pengukurannya Analisis Di Bidang Pendidikan. Bandung : Bumi Aksara

[7] Hasibuan, Melayu Sp. 2014. Manajemen Sumber Daya Manusia. Edisi Revisi. Jakarta : Bumi Aksar

[8] Hidayat, A. A. 2009. Pengantar Kebutuhan Dasar Manusia Aplikasi Konsep. Keperawatan Buku 1. Jakarta: Salemba Medika

[9] Komisi Penanggulangan AIDS Nasional. 2009. Situasi HIV Dan AIDS Di Indonesia. Jakarta

[10] Komisi Penanggulangan AIDS Nasional. 2010. Info HIV Dan AIDS. Jakarta

[11] Mustikawati, R. I et al. 2013. Strategi Pemberdayaan Ekonomi Komunitas Waria Melalui Life Skill Education.

[12] Nasronudin. 2007. Pengembangan Pengetahuan Penyakit Infeksi HIV Dan AIDS, HIV dan AIDS Pendekatan Biologi Molekuler, Klinis, dan Sosial. Editor: Barakbah J, Soewandojo E, Suharto, Hadi U, Astuti WD. Surabaya: Airlangga University Press 
[13] Nasronudin. HIV/AIDS. In. 2007. Penyakit Infeksi Di Indonesia Solusi Kini Dan Mendatang. Editor: Hadi U, Vitanata, Erwin AT, Suharto, Bramantono, Soewandojo E. Surabaya: Airlangga University Press

[14] Notoatmodjo, S. 2010. Metodologi Penelitian Kesehatan. Jakarta: Rineka Cipta.

[15] Nursalam. 2015. Manajemen Keperawatan Aplikasi Dalam Praktik Keperawatan Profesional. Jakarta : Salemba Medika

[16] Patricia Ann Potter; Anne Griffin Perry; Amy Hall; Patricia A Stockert. 2013 Fundamentals of Nursing

[17] Robbins dan Judge. 2007. Perilaku Organisasi. terj. Diana Angelica. Jakarta : Salemba Empat (pp. $230-233$ )

[18] Ryadi, Slamet \& T. Wijayanti. 2007. Dasar-Dasar Epidemiologi. Jakarta :Salemba Medika.

[19] Sigmund Freud. 2006. Pengantar Umum Psikoanalisis, terj. Haris Setiowati Yogyakarta: Pustaka Pelajar

[20] UNAIDS. 2011. UNAIDS World AIDS Day Report 2011. Geneva, Swizerland

[21] WHO. 2010. WHO Case Definitions Of HIV For Surveillance And Revised Clinical Staging And Immunological Classification Of Hiv Related Disease In Adult And Children. Geneva (Switzerland)

[22] WHO. HIV/AIDS. Available from :http://www.who.int/topics/hiv aids /en/. 